\title{
Analysis of Agra Mas Bus Service Level Case Study of PGC East Jakarta Route - Soekarno Hatta International Airport
}

\author{
Widodo Budi Dermawan and Bambang Adi Setiawan \\ Faculty of Engineering, University Mercu Buana Jakarta, Indonesia \\ wbdermawan@gmail.com, barbambang123@gmail.com
}

\begin{abstract}
The method used in this study is the Importance Performance Analysis (IPA) method. This research was conducted to determine passenger satisfaction, evaluate service levels by referring to service standard indicators from the Directorate General of Land Transportation. The results of the Bus Operational Performance analysis results refer to the Directorate General of Land Transportation standards, the overall results of operational performance have been included in the Good category with a value of 24 points. the results of the questionnaire stated that the service performance was very good (SB) by $16 \%$; Good (B) of 52\%; Fairly Good (CB) of 25\%; Poor (KB) by $6 \%$ and Not Good (TB) by 0\%, with reference to the 5 Likert scale. From the Cartesian diagram there are several aspects of concern regarding the level of service, quadrant I there are 8 attributes that are considered important by consumers and their service is very satisfying, Quadrant II there are 1 atributes that are considered very important by customers but the service is not satisfactory.
\end{abstract}

Keywords: Agra Mas, Operations, Services, Importance Performance Analysis

\section{Introduction}

The Agra Mas Bus is one of the public transportation facilities provided by the private sector which was formed in 1985 founded by Mr. Tony[1]. The first route of the fleet starts from the Karawang route and extends to Jabodetabek until 2014 Jabodetabek (BPTJ) transportation management agency cooperates with PO Agra Mas launches Jabodetabek Airport, PO. Agra Mas serves the bus route PGC East Jakarta - Soekarno Hatta International Airport, this is the second route which has now expanded to three new routes that were inaugurated in 2018 namely the Pondok Gede Atrium route (APG) - Soekarno Hatta International Airport[2], with the main task organizing transportation of people and goods on the road using motorized vehicles. In the next development as a private company, the name of Agra Mas was enshrined as a mark of the brand from a Private-Owned Enterprise (BUMS), which until now still consistently carry out its duties as one of the providers of transportation of people and goods by using the bus.

Based on the background outlined above, facilities and services may be declining and there are no periodic updates so customers are not satisfied with the services provided.

\section{Methodology}

Importance Performance Analysis is a method used to solve the formulation of problems regarding the level of customer / passenger satisfaction. Companies / services / organizations that prioritize the interests of customers and company performance will get a value measuring the appropriate level of satisfaction[3]. 


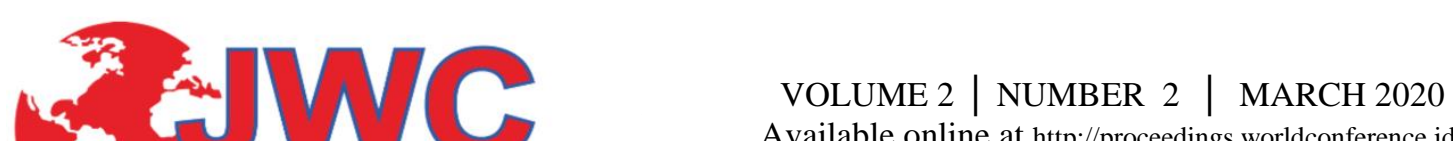

Available online at http://proceedings.worldconference.id.

ISSN: 2656-1174 (online)

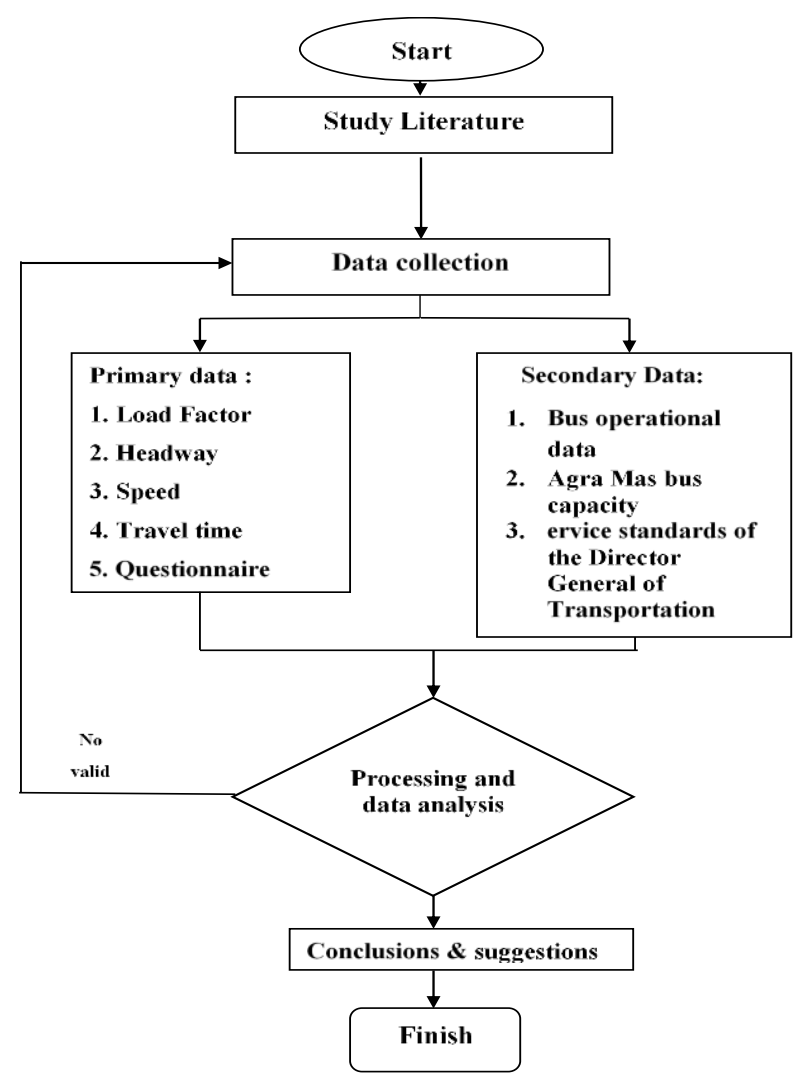

Figure1. Research flowchart

Source: Data in research, 2020

\section{Determine the Number of Respondents}

To determine the number of respondents used the sampling method. Here is the Slovin formula used to determine the number of respondents:

$\mathrm{n}=\frac{9845}{\left(1+9845(0.1)^{2}\right.}$

Information:

$\mathrm{n} \quad=$ number of samples

$\mathrm{N} \quad=$ total population

$\mathrm{E} \quad=$ percent leeway for inaccuracy, $10 \%$

obtained $n=98.99=100$ inhabitants, then the required sample of 100 respondents[4].

\section{Result and Discussion}

\subsection{Importance Performance Analysis (IPA)}

In the Importance Performance Analysis (IPA) technique, respondents are asked to rate the level of customer satisfaction with a service by measuring the level of importance by their implementation. Importance Performance Analysis (IPA) formula: Primary data collection was carried out by conducting a direct survey in the field of the East Jakarta PGC route - Soekarno Hatta Airport. The survey was conducted for 2 days namely on weekdays and holidays by taking 2 bus / direction samples (rush hour \& outside rush hour). The types of surveys carried out are by means of observation, interviews, documentation and distribution of questionnaires (on-bus)[3].

One day of research is conducted on weekdays Monday to Friday, but taken only one day namely Monday to represent data collection Rush hour: 07:00 - Finish Outside rush hour: 13:00 - Finish One day of research conducted on a holiday that is Saturday or Sunday, but taken only one day to represent data collection on Saturday. Busy Hours: 07:00 - End Outside Busy Hours: 13:00 - End. 
Table 1. Overall Results of Operational Performance

\begin{tabular}{|c|c|c|c|c|c|}
\hline No & Indicator & $\begin{array}{l}\text { Survey } \\
\text { Results }\end{array}$ & $\begin{array}{c}\text { Director } \\
\text { General of Land } \\
\text { Transportation } \\
\text { Standards } \\
\end{array}$ & Category & Qty \\
\hline 1 & Load Factor during rush hour & $0.58 \%$ & $<0.8 \%$ & A & 3 \\
\hline 2 & Load Factor outside the rush hour & $0.45 \%$ & $<0.7 \%$ & A & 3 \\
\hline 3 & Time between / Headaway & 28.5 & $>15$ & $\mathrm{C}$ & 1 \\
\hline 4 & Travel time & 1.62 & $<6$ & A & 3 \\
\hline 5 & Service Time & 16 & $>15$ & A & 3 \\
\hline 6 & Kecepatan Perjalanan & $39 \mathrm{~km} / \mathrm{jam}$ & $>10 \mathrm{~km} / \mathrm{jam}$ & A & 3 \\
\hline 7 & Frequency & 3 & $<4$ & $\mathrm{C}$ & 1 \\
\hline 8 & Number of vehicles operating & $100 \%$ & $>82-100 \%$ & B & 2 \\
\hline 9 & Waiting time & $20-30$ & $20-30$ & B & 2 \\
\hline \multirow[t]{3}{*}{10} & Beginning and End of Service Time & $04: 00-20: 00$ & $05-22$ & A & 3 \\
\hline & Average total & & & & 2.4 \\
\hline & Operational Performance Appraisal & & & & $\mathrm{B}$ \\
\hline
\end{tabular}

There are several elements that can be used as a reference and describe the expected characteristics of transportation as determined by the government regarding Minimum Service Standards for Users of Special Airport Transportation Services [5].

\subsection{Results of Performance Analysis and Satisfaction Level Based on Questionnaire:}

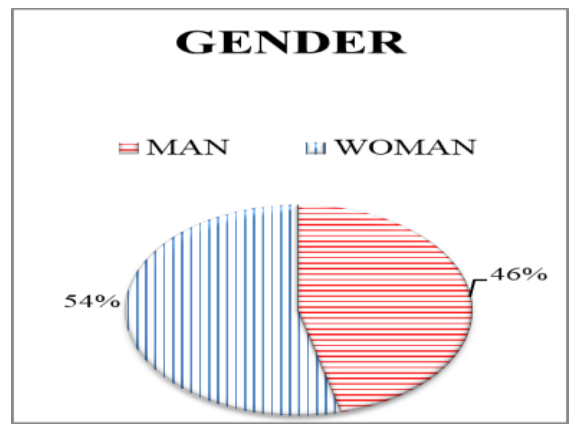

Figure 2. Gender Circle Graph

Source: Data in research, 2020

It can be seen that the number of respondents who have male sex are 46 people or $46 \%$ and the respondents have female sex as many as 54 people or $54 \%$ of 100 respondents[6].

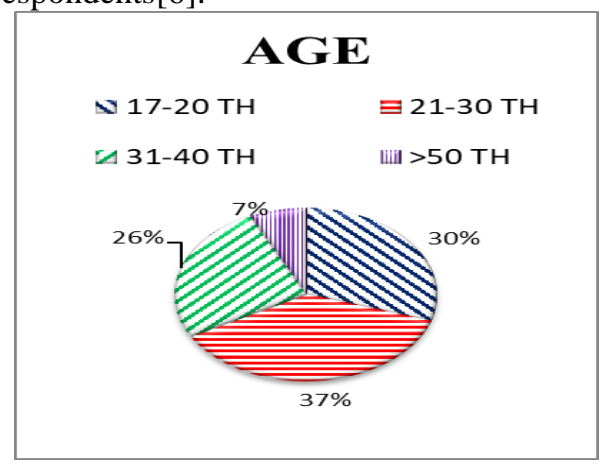

Figure 3. Age Circle Graph

Source: Data in research, 2020

Based on the above data the age of the respondents ranged, 17-20 years with 30 people or $30 \%$ of 100 respondents, 21 30 years with 37 people or $37 \%$ of 100 respondents, 31 - 40 years with 26 people or $26 \%$ of 100 respondents, > 50 years with 7 people or $7 \%$ of 100 respondents[6]. 


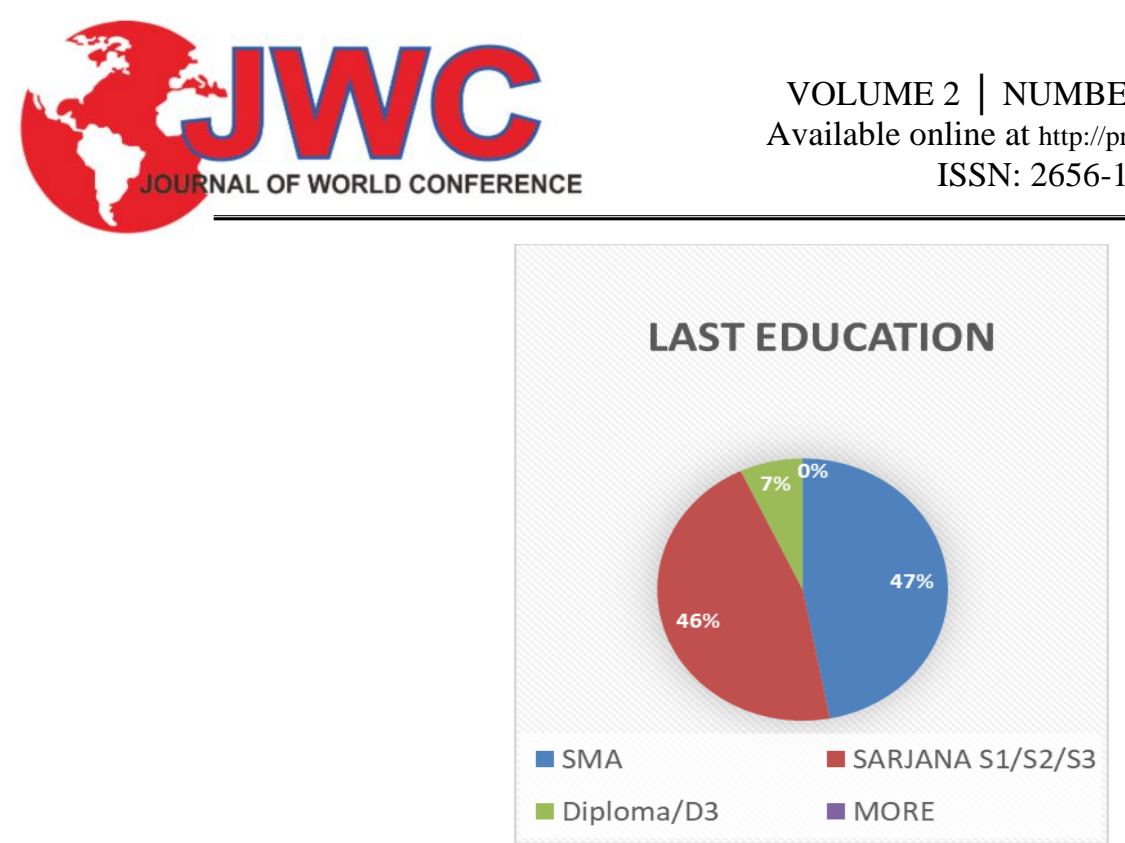

Figure 4. Latest Education Graph

Source: Data in research, 2020

Based on the data above the last education of the respondents ranged, high school with 47 people or $47 \%$ of 100 respondents, Diploma / D3 with 7 people or 7\% of 100 respondents, Bachelor's degree / S2 / S3 with 46 people or $46 \%$ of 100 respondents, Others with 0 people or $0 \%$ of 100 respondents[6].

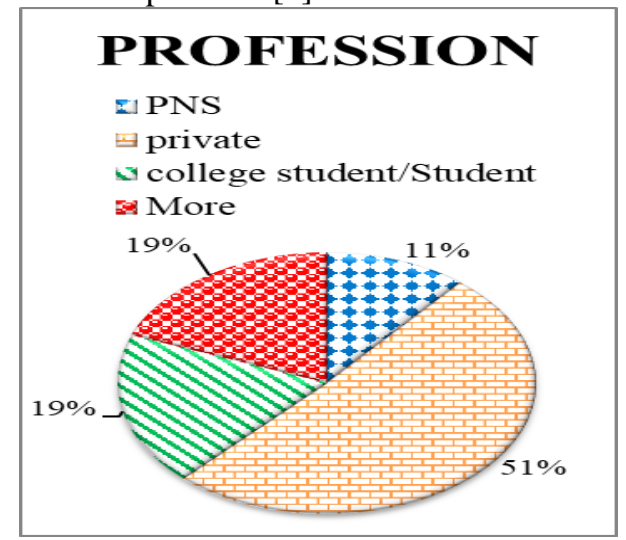

Figure 5. Latest Education Graph

Source: Data in research, 2020

Based on the above data the work of the respondents include civil servants, with 11 people or $11 \%$ of 100 respondents, private with 51 people or $51 \%$ of 100 respondents, students / students with 19 people or $19 \%$ of 100 respondents, others with 19 people or $19 \%$ of 100 respondents[6].

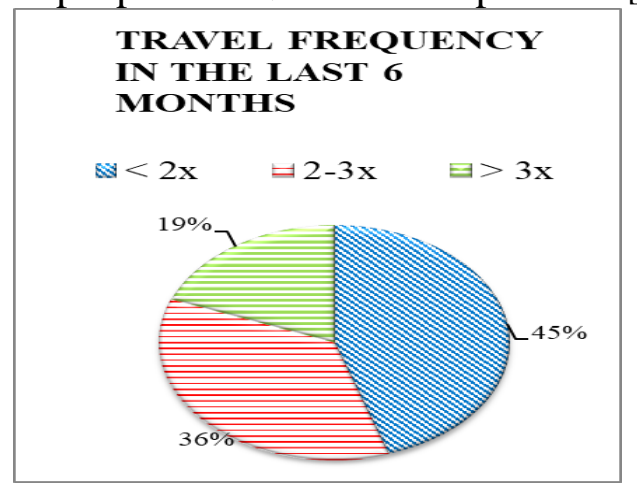

Figure 6. Latest Education Graph

Source: Data in research, 2020 
Based on the data above Frequency of Travel In the last 6 months the respondents included $<2$ times with 45 people or $45 \%$ of 100 respondents, 2-3 times with 36 people or $36 \%$ of 100 respondents, $>3$ times with 19 people or $19 \%$ of 100 respondents[6].

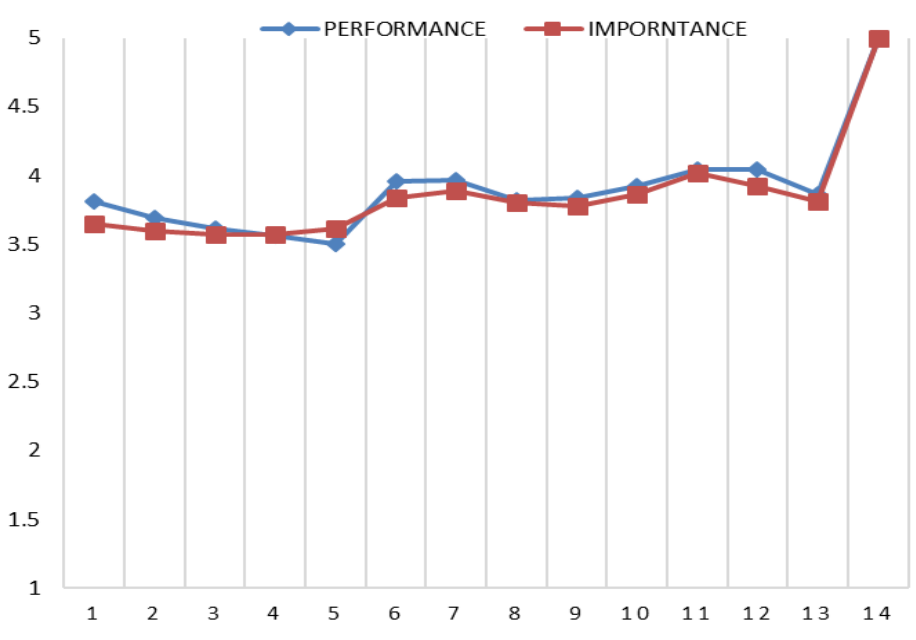

Figure 7. Graph of Results of Calculation of Average Questionnaire Source: Data in research, 2020

From the calculation results of the above average data as a whole can be concluded:

1. The average of the assessment of the quality of performance is 3.90, it can be said that the respondents' assessment of the quality of performance is good.

2. The average rating of the satisfaction level is 3.85 , it can be said that the respondents' assessment of the satisfaction level is satisfied[7].

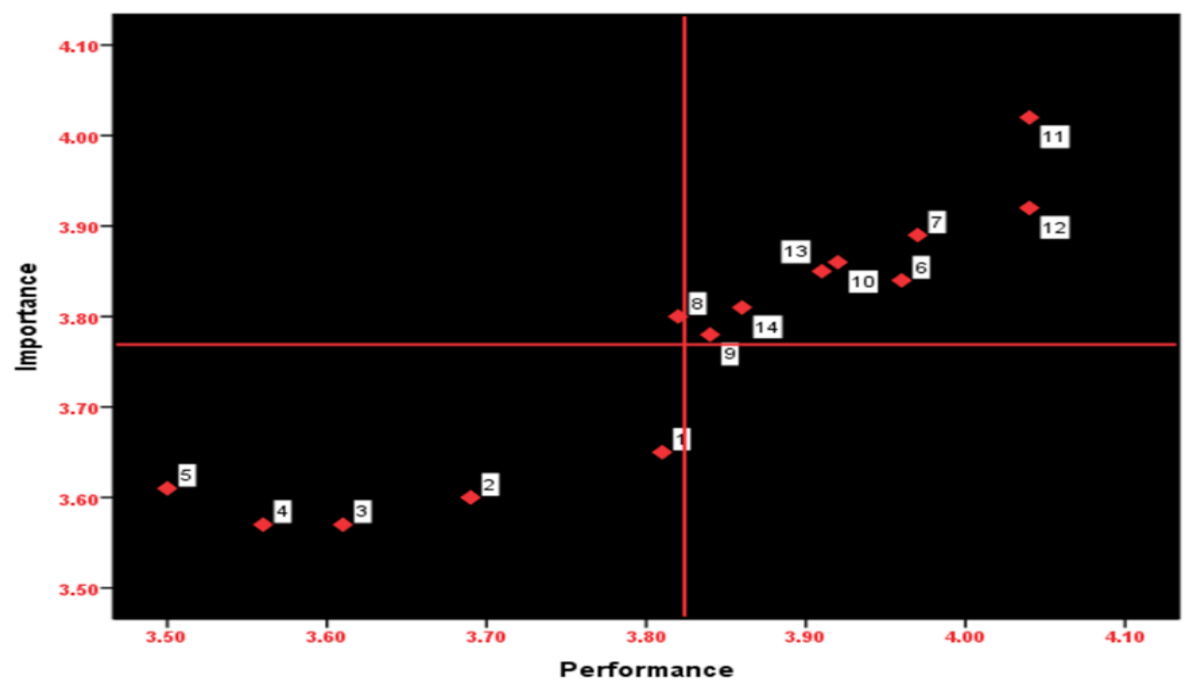

Figure 8. Cartecius Diagram

Source: Data in research, 2020

Based on the results of the Cartesian Output diagram above, it can be concluded:

\subsection{Quadrant I (Keep Up The Good Work)}

Based on the results of the questionnaire survey assessment of respondents there are variables that fall into Quadrant I this attribute is considered very important and the service is very satisfying, the company must maintain it, namely[8]:

1. Attribute 6: Feeling safe while using the services of the bus fleet 
2. Attribute 7: Understanding bus staff needs / feelings of passengers

3. Attribute 9: A clean and comfortable waiting room / place

4. Attribute 10: The neat appearance of the bus staff

5. Attribute 11: The existence of clear information boards in the room / passenger waiting area

6. Attribute 12: Physical condition of the bus fleet and facilities inside the bus (seating, air conditioning, etc.)

7. Attribute 13: Bus fleet cleanliness

8. Attribute 14: Conditions and eligibility of safety equipment inside the bus

\subsection{Quadrant II (Concentrate Here)}

Based on the results of the questionnaire survey assessment of respondents, there are several variables that fall into Quadrant II. In this quadrant the respondent considers this attribute to be very important but its service is unsatisfactory. These variables are[8]:

1. Attribute 8: Ease in establishing relationships, effective communication

\subsection{Quadrant III (Low Priority)}

Based on the results of the questionnaire survey assessment of respondents, there are several variables that fall into Quadrant III. This attribute is considered not important and its service is not satisfactory[8]. These variables are:

1. Attribute 1: Accuracy of arrival and departure times

2. Attribute 2: Reliability of the bus in delivering services from beginning to end

3. Attribute 3: Bus staff's willingness to provide services quickly

4. Attribute 4: Submission of clear information from the bus staff

5. Attribute 5: The certainty of getting a ticket

\subsection{Quadrant IV (Excessive)}

Based on the survey results there are no variables that enter into quadrant IV[8].

\section{Conclusion:}

Based on the results and analysis that have been done, conclusions can be drawn from the results of this study:

1. Based on the results of the analysis of the Agra Mas Bus Operational Performance in the PGC - Soekarno Hatta Airport route that refers to DGCA standards, the overall results of operational performance have been included in the "Good" category with a value of 2.4 points.

2. From the results of the questionnaire filled out by respondents or users of the Agra Mas PGC bus service - Soekarno Hatta Airport, stated that the service performance was very good (SB) of 16\%; Good (B) of 52\%; Fairly Good (CB) of 25\%; Poor (KB) by $6 \%$ and Bad (TB) by $0 \%$, with reference to 5 service Likert scales regarding the performance of the Agra Mas bus service - Soekarno Hatta Airport.

3. Quadrant I, there are 8 attributes that are considered important by consumers and their service is very satisfying. Conclusion consumers are satisfied, and companies must maintain quality attributes that are in quadrant I.

4. Quadrant II, there is one attribute that is considered very important by the customer but the service is not satisfactory. This attribute is a top priority for immediate improvement by the company. Conclusion The company prioritizes to focus on improving the attributes that are in this quadrant, because the quality of performance is not satisfactory.

\section{Suggestion:}

Based on the results of the analysis that has been done, there are several suggestions from the authors for third parties, namely:

1. The company must prioritize making improvements in order to improve the quality of service that is deemed unsatisfied customers will service to bus customers.

2. The company must maintain aspects that are valued by customers and its service is very satisfying contained in quadrant I Cartesian diagram (IPA).

\section{References}

[1]. Media Indonesia, (2019). Web page. Retrieved from http://herkytransportation.blogspot.com/p/po-agra-mas.html.

[2]. Media Indonesia, (2019). Web page. Retrieved from https://www.republika.co.id/berita/nasional/jabodetabeknasional/18/10/19/pgtidr383-bptj-gandeng-agra-mas-luncurkan-bus-pondok-gedebandara. 
[3]. Martilla, \& James. (1977). Importance Performance Analysis. The Journal Of Marketting, 77-78.

[4]. Sevila, C. G., \& al, E. (1993). In Pengantar Metodologi Penelitian. Jakarta: Universitas Indonesia.

[5]. Standart Dirjen Perhubungan Darat SK.22.AK.005/UAKB(2012).

[6]. Martono, N. (2014). Metode Penelitian Kuantitatif: Analisis Isi dan Analisis Data Sekunder. Depok: PT Rajagrafindo Persada.

[7]. Martilla, \& Jhon C, J. (1997). Pentingnya Analisis Kinerja. 77-79.

[8]. Martilla, \& James. (1977). Importance Performance Analysis. The Journal Of Marketting, 77-78.

\section{Biographies}

Widodo B. Dermawan is a Practitioner as well as a Lecturer in Civil Engineering, especially in the field of Transportation, he took Strata 1 at Parahyangan Catholic University, and took his Masters at the University of Wisconsin-Madison. In the world of education, he teaches at Mercu Buana University (Meruya), University of Indonesia (Depok).

Bambang A. Setiawan is a student of the Faculty of Civil Engineering at Mercu Buana University in 2015 and successfully completed his undergraduate education in February 2020. Mr. Setiawan is also working in a book manufacturing company located in East Jakarta with the position of production operator, vocational education background with graduates Automotive Engineering in 2013. 